\title{
Apontamentos sobre o processo de revisão do Plano Diretor da cidade de Niterói
}

\author{
Regina Bienenstein \\ Glauco Bienenstein \\ Daniel Mendes M. de Sousa \\ Cynthia Gorham
}

\section{RESUMO}

Este artigo discute o processo de revisão do Plano Diretor de Niterói, defasado em mais de 13 anos e objeto de reivindicação de movimentos sociais da cidade. Avalia-se que tal processo não tem se dado de forma linear ou sem contradições, uma vez que diferentes visões de cidade têm sido apresentadas e discutidas, impondo escolhas aos governantes. Neste contexto, considerase oportuno refletir, mesmo que preliminarmente, sobre tais escolhas, assim como avaliar perspectivas futuras para a cidade de Niterói. No Brasil, a luta pela ampla redemocratização do país e das cidades, o enfrentamento deste novo cenário e a crise fiscal contribuíram para que duas propostas antagônicas disputassem as escolhas sobre os destinos das cidades. Uma, no sentido da garantia da função social da propriedade e da cidade, viabilizada pela Constituição de 1988 e reafirmada no Estatuto da Cidade, a partir de 2001. E outra, progressivamente adotada nos municípios brasileiros, subordinada pelos ditames do mercado, visando, segundo seus apologistas, atrair novos investimentos. Desse modo, analisa-se como se deram os embates dessas duas propostas, ora examinando a capacidade do governo de efetivar suas propostas e como se deu o apoio de sua base de suporte social e no parlamento e ainda, como seus antagonistas responderam a essas propostas. 0 artigo está organizado em quatro partes. A primeira contextualiza o processo de planejamento recente da cidade; a segunda analisa as novas e contemporâneas formas de pensar e agir sobre a cidade que têm sido adotadas na história recente de Niterói; a terceira examina o conteúdo das atualizações propostas na revisão do Plano Diretor; finalmente, nas conclusões, são apresentadas algumas incoerências e as oportunidades abertas pelo processo aqui analisado, visando oferecer elementos que possam contribuir para com as lutas por uma cidade mais justa e igualitária.

PALAVRAS-CHAVE: Plano diretor (Revisão); Planejamento (Urbano); Niterói.

\section{ABSTRACT}

This article deals with the review process of the master plan of Niterói city. It is here sustained that this process has not occurred without contradictions, since different views about the city have been presented and discussed, imposing choices to the urban administrators. Thus, we sustain that it is important to make some preliminary remarks on the urban planning process of Niterói city, as it can illustrate how the urban process is taking place in Brazilian medium sized cities nowadays. Moreover, it is considered opportune to reflect, even preliminarily, on such choices, as well as to evaluate future prospects about the challenges posed to the city. The Brazilian re-democratization process and the challenges that have been faced by the different government levels since then, have contributed to the emergency of two different views: one connected to the struggle to the return to democracy, in 1985, and with what has been prescribed by the 1988 Brazilian Constitution, and the other linked to the market-friendly agenda in order to face the challenges that have been posed by the so-called globalization process. Therefore, it is analyzed how these views have been confronted. The article is organized in four parts. The first one, which opens the article, briefly contextualizes the urban planning process in Niterói city in the recent years. The second analyzes the market-friendly strategies that have been carried out by recent urban administrations of the city. The third examines the review process of master plan. Finally, some remarks about the proposals included in the master plan review are presented as well as how decision-making process has occurred during the discussions. Closing the article, it is indicated some inconsistencies and opportunities that have been presented in the master plan review process in order to support social struggles towards the right to the city.

KEYWORDS: Master plan (Review); Urban planning; Niterói 


\section{1. À Guisa de Introdução: contextualizando o processo de planejamento em Niterói}

A cidade de Niterói, localizada à beira da Baía de Guanabara, em frente à cidade do Rio de Janeiro (Figura 1), e com uma população de quase $500 \mathrm{mil}$ habitantes, apresenta grandes desigualdades socioespaciais: uma classe média forte (renda familiar entre as mais altas no estado e $67 \%$ da força de trabalho empregada são de universitários). Mas este cenário também inclui mais de 40.000 casas distribuídas em 87 favelas carentes de infraestrutura urbana e com riscos de deslizamentos ou de inundações (AUTOR, et. al., 2012). A elas se soma um expressivo número de famílias de baixa renda, ocupando edificações abandonadas e mesmo em situação de rua, por não conseguirem se incluir no mercado formal. Isto é, no município que se destaca na Região Leste Metropolitano pelo seu alto IDHM $^{1}$ e pela cobertura expressiva de serviços públicos, encontram-se cerca de $25 \%$ de sua população total vivendo em situação de precariedade.

Figura 1 - Localização de Niterói - Autor: Raphael Lorenzeto de Abreu, 2006.

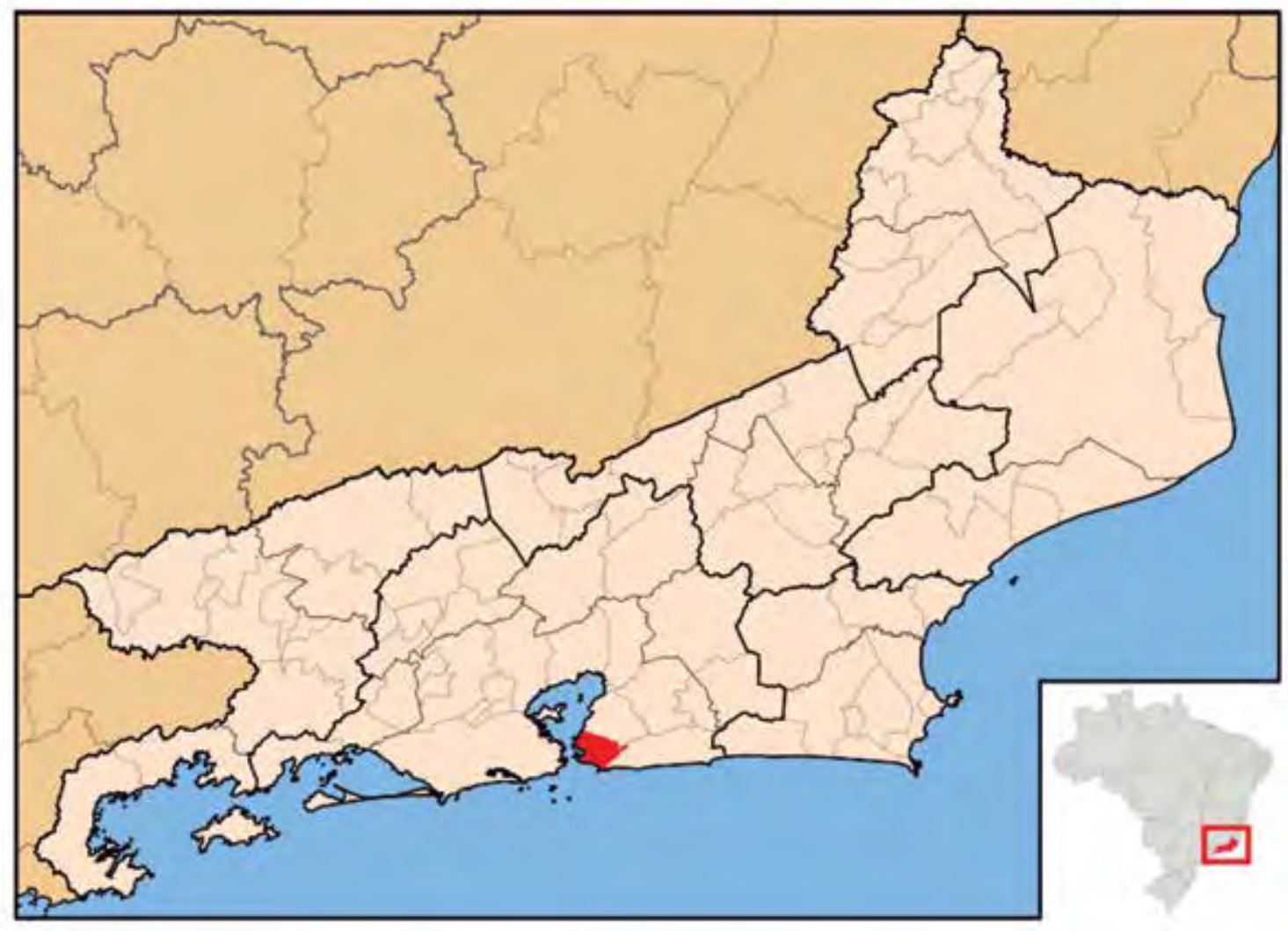

Fonte: Disponível em: 〈https://pt.wikipedia.org/wiki/Niter\%C3\%B3i〉. Acesso em: 17.02.2018

Embora este artigo centre sua análise a partir da década 1990, quando da aprovação do Plano Diretor para Niterói, em 1992, é importante considerar dois eventos anteriores que provocariam importantes mudanças na cidade, desde 1903, quando esta passou a ocupar a posição de capital do estado. O primeiro

1 IDHM - Índice de Desenvolvimento Humano Municipal é composto de indicadores comparativos de três dimensões do desenvolvimento humano: longevidade, educação e renda. 
refere-se à inauguração, em 1974, da Ponte Rio Niterói que provocou um considerável aumento populacional - cerca de $25 \%$ em 10 anos, passando de aproximadamente 320 mil para quase 400 mil habitantes; e, em seguida, em 1975, a perda da centralidade institucional e administrativa, com a fusão dos estados do Rio de Janeiro e da Guanabara, e a transferência do status de capital para a cidade do Rio de Janeiro. Niterói perde assim sua importância políticoadministrativa, sofrendo relevantes danos econômicos que se refletiram em todo o seu território. Com o aumento de sua população, a cidade passa a enfrentar problemas de outra escala e natureza, especialmente de infraestrutura (drenagem e saneamento) bem como de mobilidade.

Durante o período compreendido entre os anos 1977 e $1982^{2}$, tais problemas foram utilizados como justificativa para um crescente endividamento do município, com o intuito para realizar obras voltadas para melhorias do sistema viário e que resultou, no período seguinte (1982 e 1989³), em uma fase de estagnação que deixaria a cidade praticamente abandonada. Vale, todavia, lembrar que também durante esta década, o Brasil enfrentou problemas diversos em função de processos dialeticamente articulados, a saber, o colapso da estrutura produtiva e industrial e o surgimento de inovações tecnológicas no campo da microeletrônica e da automação, sob a égide do então emergente capitalismo de corte predominantemente financeiro. Por outro lado, o final da década de 1980, com a Constituição de 1988, marcou a descentralização política, a municipalização das receitas e o reforço de seu papel, possibilitando a volta de investimentos na cidade e a responsabilidade sobre o território. Ou seja, a redemocratização, em 1985, acabou ocorrendo num período de consideráveis e distintos eventos que tornaram ainda mais complexo o processo de discussão e definição dos destinos da nação, aí incluídas suas unidades políticoadministrativas, ou seja, estados e municípios.

Segundo Omena (2016, p.138), durante o processo de transição que marcou a redemocratização do país e que ficou conhecido como "Nova República" ${ }^{4}$, houve o aprofundamento de duas tendências da institucionalidade: mediações formais entre Estado e sociedade e as reformas neoliberais, que se complementaram de forma contraditória nas últimas duas décadas.

Neste contexto, a constituição dos Conselhos Gestores, Orçamentos Participativos e ações de marketing urbano se disseminaram a partir dos anos 1990, num ambiente de crescente protagonismo das municipalidades aliado a um não menos crescente aumento do ativismo na sociedade civil, tanto dos movimentos, quanto do setor empresarial na administração pública. Isto acarretou na adoção de mecanismos e/ou instrumentos tais como privatizações, parceiras público-privadas, crescimento de técnicas empresariais na gestão pública, entre outros, que apresentavam um potencial de conflito em relação aos princípios progressistas constantes na nova legislação urbana (OMENA, id. ibid.).

Com a eleição de Jorge Roberto Silveira (PDT), em 1988, observa-se a emergência de um novo grupo político que se utilizou do resgate da sensação de pertencimento

2 Administração Moreira Franco (MDB/1977 a 1982).

3 Administração Waldenir Bragança (PDS/1982 a 1988).

4 Período imediatamente posterior ao Regime Militar, quando uma expressiva parcela da sociedade brasileira vivenciou um novo período político no país, com eleições diretas, elaboração e aprovação de uma nova constituição, entre outras não menos importantes conquistas. 
e orgulho dos moradores de Niterói, os quais sempre foram obnubilados pela centralidade e pujança do Rio de Janeiro. Nesta direção, foram realizados consideráveis investimentos em serviços públicos, além de ser elaborado seu primeiro Plano Diretor ${ }^{5}$ em 1992 - portanto, antes da obrigação constitucional, revelando-se uma medida progressista -, com validade de 10 anos. Este Plano, "com base em critérios de homogeneidade em relação à paisagem, à tipologia, ao uso das edificações e ao parcelamento do solo, [considerando] ainda, aspectos socioeconômicos e físicos, em especial as bacias hidrográficas", dividiu a cidade em cinco regiões: Praias da Baía, abrangendo o Centro e os bairros da orla da Baía de Guanabara, de Icaraí até Jurujuba; Norte, compreendendo os bairros da Ilha da Conceição, Barreto, Fonseca até Santa Bárbara; Pendotiba; Região Oceânica e a Região Leste, compreendida por Rio do Ouro e Várzea das Moças (Figura 2).

Figura 2 - Município de Niterói e suas regiões.

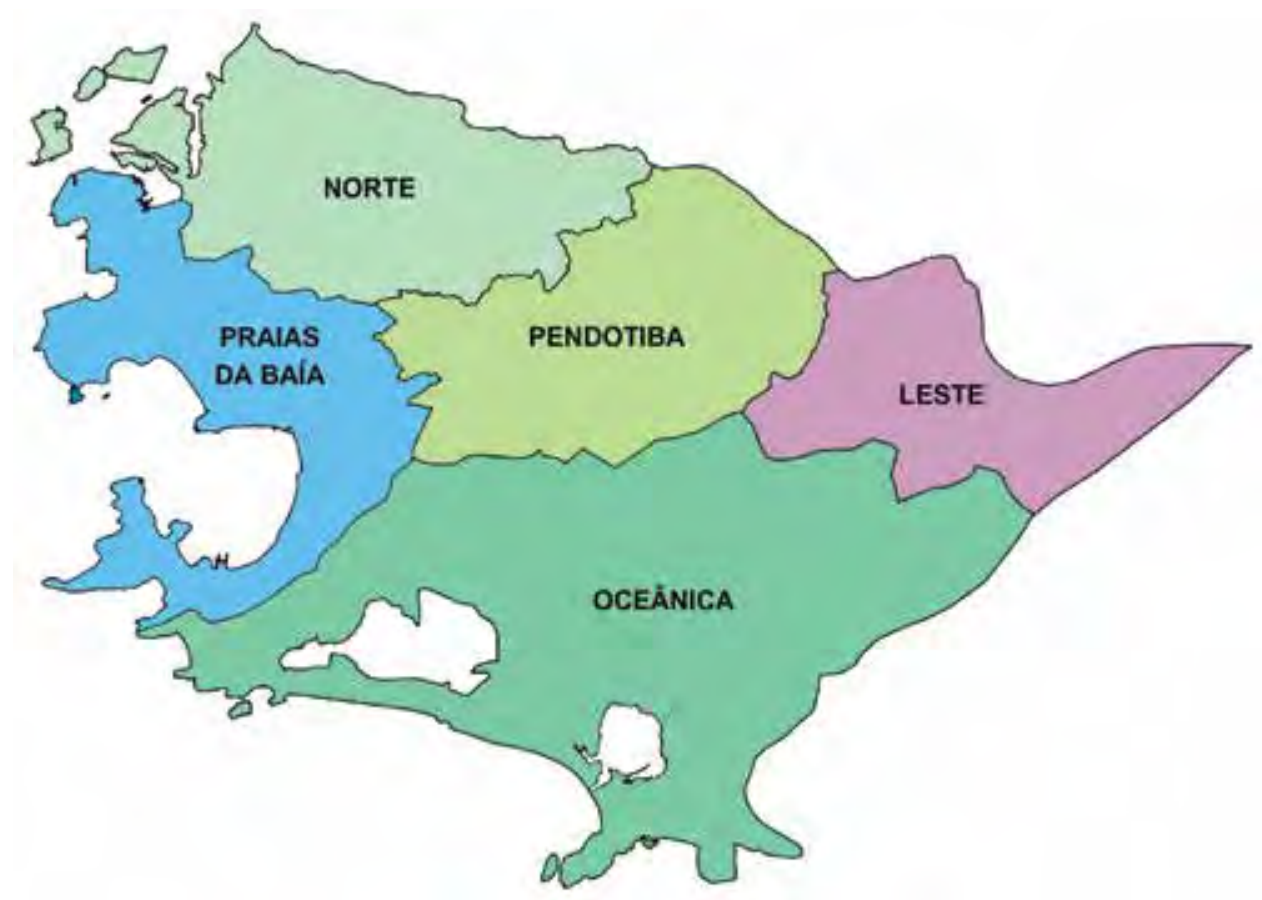

Fonte: Fdelpomo, 2013. Disponível em: 〈https://pt.wikipedia.org/wiki/Lista_de_bairros_de_Niter\%C3\%B3i\#/media/ File:Regi\%(3\%B5esNiteroienses.jpg〉.

O Plano Diretor de 1992 incorporou, por um lado, instrumentos que possibilitariam o cumprimento da função social da propriedade e da cidade, como a demarcação de ZEIS ${ }^{7}$ em áreas ocupadas por assentamentos populares precários, oferta de instrumentos de regularização fundiária e recuperação de mais valia por ocasião da aprovação de empreendimentos imobiliários. Embora tenha transferido o detalhamento das normas de uso e ocupação do solo para

$5 \quad$ Embora em 1976, Niterói tivesse seu primeiro plano diretor elaborado pelo escritório WitOlaf Prochnik Arquitetura e Planejamento, na gestão do primeiro prefeito pós a fusão, Ronaldo Fabrício (1975/76), este plano não foi implementado.

$6 \quad$ Artigo 108 da Lei no 1.157/1992, Plano Diretor de Niterói.

$7 \quad$ ZEIS - Zona de Especial Interesse Social. 
os Planos Urbanísticos Regionais ${ }^{8}$, enquanto não fossem aprovados, as regiões estariam submetidas a parâmetros gerais, o que, em um primeiro momento, não parecia ser um problema, pois a perspectiva dos técnicos e dos movimentos sociais que participavam do processo era de que os prazos e exigências seriam cumpridas. Todavia, como será visto adiante, o detalhamento não ocorreu, o que gerou diversas lacunas que foram sendo preenchidas, na maioria das vezes, por meio de iniciativas, as quais, na ampla maioria das vezes, não lograram os benefícios esperados pelos movimentos sociais.

Desse modo, conforme Villaça (2010) sugere, o Plano Diretor e seus respectivos instrumentos, não significou, no caso aqui analisado, avanço nas políticas públicas que poderiam beneficiar os territórios populares. Aliás, a este respeito, o referido autor tem apontado uma discussão importante sobre a ineficácia das legislações, argumentando que sua aplicação, mesmo que pareça atender às demandas populares, não necessariamente significa certeza sobre seus efeitos democratizantes para a cidade. Se as propostas não se transformam em políticas efetivas, o processo participativo que as consolida parece servir como um "instrumento" que acaba por frear (e até mesmo inviabilizar) as reinvindicações populares! Conforme dito acima, este paradoxo pode ser entendido quando se analisa o processo que vivido na cidade de Niterói.

Esta contradição aparece quando, em paralelo ao processo de construção do Plano Diretor de 1992, um novo modelo de planejamento e governança urbana foi adotado, impulsionado pela concorrência entre as cidades, como forma de fazer frente à crise financeira na disputa por investimentos. As mudanças experimentadas pelo capitalismo resultaram no redirecionamento das formas de pensar e de administrar as cidades mundo afora, repercutindo, talvez com maior impacto, naquelas situadas na periferia, tais como Niterói que, por sua vez, passou a buscar soluções que poderiam ser identificadas com o que Harvey (1996, p.48) nomeou de "empresariamento urbano".

Intervenções pontuais de "revitalização urbana", flexibilização dos parâmetros construtivos e a crescente adoção de Operações Interligadas ${ }^{10}$, obras de infraestrutura e melhorias concentradas em bairros residenciais das classes de maiores rendas, somadas à construção do Museu de Arte Contemporânea

8 Art. $6^{\circ} \mathrm{O}$ Município de Niterói está estruturado em um modelo de organização territorial estabelecido no Plano Diretor e consolidado na Lei de Uso e Ocupação do Solo, tratando esta Lei especialmente das seguintes divisões territoriais: I - Macrozonas Ambientais; II - Regiões e Sub-Regiões de Planejamento [grifo nosso]; III - Frações Urbanas; IV - Áreas de Especial Interesse; V - Unidades de Conservação Ambiental. $₫ 1^{\circ}$ As Macrozonas Ambientais dividem o território municipal em duas zonas condicionando o uso e a ocupação do solo: a) Zona Urbana - aquela adequada à urbanização, efetivamente ocupada ou destinada à expansão da Cidade, e subdividida, de acordo com os Planos Urbanísticos Regionais [grifo nosso], em Frações Urbanas e Áreas de Especial Interesse Urbanístico, Social ou Econômico. b) Zona de Restrição à Ocupação Urbana - aquela que abrange as áreas cujas condições físicas são adversas à ocupação urbana por características geológicas, paisagísticas, topográficas, de cobertura vegetal e de importância para preservação de espécies nativas de flora e fauna. $₫ 2^{\circ} \mathrm{A}$ divisão territorial correspondente às regiões de planejamento e serve como demarcação dos Planos Urbanísticos Regionais [grifo nosso]. Disponível em: <https://leismunicipais.com.br/plano-de-zoneamento-uso-eocupacao-do-solo-niteroi-rj>. Acesso em: 19/02/2018.

9 Para um maior aprofundamento desta questão, consultar Harvey, David. "Do gerenciamento ao empresariamento: a transformação da administração urbana no capitalismo tardio”, Espaço e Debates, ano XVI, n 39, 1996, p.48- 64.

10 “A Operação Interligada, prevista no Art. 17 da Lei $n^{\circ}$ 1.157/92, é a permissão de alteração de determinados parâmetros urbanísticos mediante contrapartida do interessado, respeitando-se a política global de desenvolvimento urbano da Cidade e o interesse do Município." Disponível em: $<$ https://leismunicipais.com.br/a/rj/n/niteroi/lei-ordinaria/1999/173/1732/lei-ordinaria-n-1732-1999estabelece-normas-para-aplicacao-de-operacao-interligada> Acesso em: 19/02/2018. 
$(\mathrm{MAC})^{11}$ - projeto de Oscar Niemeyer, cuja peculiar forma arquitetônica, transformou-se no símbolo da cidade, entre outras iniciativas, representaram os primeiros passos no sentido da valorização da imagem da cidade e da sua consequente visibilidade, a qual, conforme indicação anterior, figurava até então, à sombra da capital do outro lado da Baía. Estas foram, na prática, algumas das prioridades deste planejamento identificado com as orientações e diretrizes do city marketing ${ }^{12}$, o qual, no âmbito das cidades do capitalismo periférico, constituía-se ainda uma novidade. Nesta vertente, críticas são associadas sempre a uma espécie de derrotismo, repercutindo negativamente no ambiente dos negócios e à imagem da cidade (BORJA, 1995). Talvez, por conta disto, os problemas efetivos da população e da cidade real, tais como a precariedade habitacional e da infraestrutura urbana, entre outros não menos importantes problemas, eram deixados sem qualquer resposta ou, no máximo, eram objeto de ações emergenciais.

A administração de João Sampaio, que sucedeu Jorge Roberto, entre os anos 1993 e $1996^{13}$, prosseguiu com algumas ações contra os efeitos do aumento de população e da consequente expansão urbana, com obras de infraestrutura de drenagem, de saneamento e principalmente de mobilidade. Data desta gestão a elaboração do primeiro Plano Integrado de Trânsito e Transportes (PITT) que, embora não tenha sido implantado em sua totalidade, se tornou a base para futuros planos ${ }^{14}$ voltados para o tratamento da referida questão. Como parte deste plano, o prefeito João Sampaio deu início também às obras do terminal João Goulart e criou a Área de Especial Interesse Urbanístico no Aterro Praia Grande ${ }^{15}$, onde foi implantado o chamado Caminho Niemeyer, que reúne uma série de edificações projetadas pelo arquiteto Oscar Niemeyer, tornando-se elemento fundamental para a construção da imagem da cidade, contribuindo também para o resgate da imagem e, por extensão, da autoestima dos niteroienses.

Ainda na gestão de João Sampaio também foi realizada a primeira versão do PUR-PB ${ }^{16}$ em 1995 (Lei ${ }^{\circ} 1.483$ ) que, no entanto, já não atendia às demandas do empresariado do mercado imobiliário local, que pressionava a administração municipal no sentido da ampliação de suas áreas de atuação.

Mesmo sem tratar a precariedade da crescente ocupação popular informal, progressivamente, o Executivo Municipal passou a divulgar a cidade por suas qualidades e pelo seu alto índice de desenvolvimento humano (IDH). A influência do setor imobiliário privado no planejamento do uso e ocupação do solo se manifesta inicialmente com a aplicação crescente do instrumento

11 O projeto do MAC representou a primeira edificação do que viria a se constituir no chamado "Caminho Niemeyer".

12 De forma bastante resumida, pode-se definir city marketing como sendo um conjunto de técnicas e de estratégias voltadas à promoção de uma cidade, visando a atração de investimentos e de turistas com demanda solvável.

13 O prefeito era arquiteto e urbanista, filiado ao PDT e do mesmo grupo político de Jorge Roberto Silveira.

14 Posteriormente, em 2003 foi elaborado o PDTT - Plano Diretor de Transportes e Trânsito e em 2009 foi realizado o Plano Lerner, do arquiteto de mesmo nome, mas nenhum destes foi implementado na íntegra.

15 O Aterrado Praia Grande se estende por toda a orla central da cidade até o bairro o Gragoatá e embora tivesse sido projetado em 1919, foi concluído apenas ao fim da década de 1970. 
da Operação Interligada, adotado como estratégia para permitir intensificar a verticalização e o adensamento, independente da legislação urbanística em vigor.

Posteriormente, avança com a proposta de revisão do primeiro Plano Urbanístico Regional das Praias da Baía (PUR-PB), região de ocupação característica de alta e média alta renda e à elaboração do PUR da Região Oceânica (PUR-RO), nova fronteira de expansão do capital imobiliário. Sob a ordem de justificação vinculada à necessidade de organizar o planejamento da cidade e impedir o uso excessivo de Operações Interligadas, que acabavam por adensar e verticalizar aleatoriamente as parcelas mais valorizadas da cidade, o Executivo apresentou e aprovou esses dois Planos Urbanísticos (PUR-PB e PUR-RO), os quais, curiosamente, propunham maior adensamento e verticalização em ambas as regiões!

A administração de Godofredo Pinto (PT), entre abril de 2002 e final de dezembro de 2008, marca a realização da adequação, em 2004, do Plano Diretor de1992 ao Estatuto da Cidade (2001). Tal adequação se deu por intermédio da mera listagem de seus instrumentos no corpo da lei, embora sem meios para serem efetivamente aplicados. Ou seja, em lugar de promover sua revisão, já que 12 anos haviam se passado desde sua elaboração, o Executivo municipal optou pelo que se poderia denominar de "ajuste cartorial” do Plano Diretor às exigências político-administrativas da época.

Observando-se em perspectiva, pode-se afirmar que este conjunto de medidas, acarretou, na realidade, uma inversão da rotina do planejamento, tratando efetivamente de partes da cidade, por intermédio dos planos urbanísticos regionais e ajustando superficialmente o Plano Diretor ao Estatuto da Cidade. Tal movimento acabou por redefinir as formas de pensar e agir sobre o desenvolvimento da cidade de Niterói. Isto pode ser claramente percebido, através das iniciativas que marcaram as propostas e decisões vinculadas ao planejamento da cidade, a saber, o tratamento da área central da cidade, com a contratação de empresa americana para elaborar o que ficou conhecido como master plan ${ }^{17}$ e a intensificação da ocupação do solo na Região Norte, com a elaboração e aprovação do Plano Urbanístico da Região Norte (PUR-RN), em 2005.

Para efeito de esclarecimento e melhor compreensão do processo político em Niterói. Neste sentido, cabe dizer que os governos doPDT e doPT administraram sucessivamente a cidade desde 1989, primeiro com Jorge Roberto Silveira (1989/92), seguido por João Sampaio (1993/96), depois por duas gestões consecutivas de Jorge Roberto (1997 a 2002. Com sua candidatura ao governo do estado do Rio, Jorge se licencia em 2002 e assume seu vice, Godofredo Pinto (PT) que se elege no pleito seguinte. Em 2009, Jorge Roberto Silveira assume seu $4^{\circ}$ mandato. Em 2013, se elege Rodrigo Neves (PT), que se reelege em 2016 pelo PV e em 2017 muda novamente de partido, aderindo ao PDT, ou seja, parece que as disputas se concentraram dentro da própria coalisão política.

Contudo, em resumo, o resultado foi a intensificação do uso do solo, principalmente nas Regiões das Praias da Baía e Oceânica, que agudizou os problemas de mobilidade e intensificou a demanda popular pela elaboração da revisão do Plano Diretor que, além de ser recomendada e aprovada em todas as Conferencias da Cidade ${ }^{18}$ que se sucederam,

17 Niterói Centro Master Plan 2026 - proposta elaborada pela empresa norte-americana HuittZollars company, anteriormente denominada Morris Architects. Disponível em: <http://www.huittzollars.com/location/international/rio-de-janeiro/niterói-centro-master-plan> Acesso em: 19/02/2018.

18 Desde 2005, por ocasião da etapa municipal da $2^{a}$ Conferência das Cidades em Niterói (Relatório Final da $2^{\mathrm{a}}$ Conferência Municipal da Cidade de Niterói), a revisão do Plano Diretor era a pauta principal, reivindicação reiterada nas conferências seguintes em 2007, 2009, 2013 e 2016 , sendo seguida pelos temas regularização fundiária e mobilidade urbana. 
se prolongou para a disputa eleitoral de 2008, se mantendo até as eleições em 2016. Porém, cabe destacar que o predomínio da cidade mercadoria estava consolidado, em detrimento de uma cidade de direitos, como será visto na próxima parte deste artigo.

\section{Niterói na nova agenda urbana: notas}

Apesar das insistentes e crescentes demandas e das promessas dos sucessivos governos municipais, a saber, Godofredo Pinto (2002-2004; 2005-2008), Jorge Roberto Silveira (19891992; 1997-2000; 2001-2002; 2009-2012), somente ao final do primeiro governo de Rodrigo Neves (2013-2016; 2017-2020), em 2016, a revisão do Plano Diretor foi colocada na pauta de discussão pelo Executivo Municipal, isto acontecendo após um período de acirramento do tratamento fragmentado e de intervenções pontuais na cidade, acompanhados de intensas manifestações pela mencionada revisão.

Contudo, vale indicar que tal movimento não se deveu a uma autocrítica por parte do Executivo Municipal, muito pelo contrário, parece ter sido parte de uma estratégia, a qual tentar-se-á elucidar no decorrer desta parte. Para tanto, temos que nos concentrar na atual administração de Rodrigo Neves e suas iniciativas.

Importante registrar que dentre as intervenções realizadas na sua administração destacamse: a proposta de requalificação de espaços e de ampliação da infraestrutura da área central da cidade composta pelos bairros de Centro, Boa Viagem, Morro do Estado, São Lourenço e Ponta D’Areia (2013) ${ }^{19}$; o "Niterói Que Queremos", uma iniciativa financiada pelo setor privado para realização de ações estratégicas para os próximos 20 anos (2013-2033), o Corredor Viário Transoceânico (iniciado em 2014), uma proposta viária que pretendia ligar as duas Regiões economicamente mais importantes do município, a saber, a das Praias da Baía e a Oceânica e o Plano Urbanístico Regional de Pendotiba (2015), iniciativas estas apresentadas como imprescindíveis para solucionar problemas emergenciais da cidade (Figura 3) e que se somavam a projetos mais específicos e pontuais tais como o Programa Região Oceânica Sustentável, a recuperação e a transformação de área de preservação central em um morro nomeado Parque das Águas, talvez uma tentativa de contemplar concomitantemente interesses privados e iniciativas mais próximas aos interesses da população.

A proposta de renovação da área central de Niterói ${ }^{20}$ se utilizou do instrumento do Estatuto da Cidade, a Operação Urbana Consorciada, a partir de um projeto básico elaborado pelo consórcio de três grandes empresas (Odebrecht, Andrade Gutierrez e OAS), que propunha a extinção de todas as normas de uso e ocupação do solo, adotadas até aquele momento, inclusive as Áreas Especiais de Interesse Social, de Interesse Urbanístico (Campi da UFF²1

19 Disponível em: <http://centro.niteroi.rj.gov.br/operacaourbana/oquee.php>. Acesso em: 19/02/2018.

20 Em Niterói, as tentativas de tratar seu Centro datam da década de 1970. A primeira referência foi identificada em documento elaborado pela Coordenadoria de Planejamento e Desenvolvimento Urbano, instituída pela administração municipal nomeada pelo governo da fusão, ainda na década de 1970. Nele, a primeira das três diretrizes urbanas apontadas referia-se à política de renovação do centro da cidade e dos centros de bairro. No final dessa década e início dos anos 1980, a questão foi retomada, sendo solicitado um projeto para a área central ao Instituto Brasileiro de Administração Municipal (IBAM), sua concretização se dando através do Projeto Comunidade Urbana de Renovação Acelerada (Projeto CURA). O Projeto Viva Centro definiu um Master Plan, que tinha como uma de suas propostas a construção do que denominavam edifícios ícones, mas não resultou em ações concretas. Em 2011, mais uma tentativa denominada Centro Expandido que propunha, através de uma OUC, o aumento de gabarito. A proposta foi rechaçada veementemente pela sociedade civil, chamada a participar da discussão por representantes de vários segmentos.

21 Posteriormente, os Campi da UFF foram excluídos da área compreendida pela OUC. 
e Caminho Niemeyer ${ }^{22}$ ) e de Preservação do Ambiente Urbano (APAU).

A proposta também extinguia e desconhecia o processo de planejamento prévio e principalmente as iniciativas, construídas ao longo de décadas, parte dele resultado da luta do movimento social que foi capaz de construir em conjunto com a Universidade Federal Fluminense, uma política de habitação de interesse social debatida e aprovada no Conselho Municipal de Política Urbana (Compur ${ }^{23}$ ), além de estudos técnicos como o Plano Municipal de Redução de Risco de Inundação e Escorregamento, realizado pelo NEPHU/UFF ${ }^{24}$.

Para a aprovação da mencionada proposta, o discurso oficial precisou descrevê-la como uma "janela de oportunidades", ou seja, uma oportunidade única de recuperar o Centro da cidade, descrito como degradado, sujo e sem dinamismo, frente a uma situação de crise financeira. Afirmou, ainda, que o projeto visava transformar a Região central do município num ambiente agradável para a habitação e para o trabalho.

Aprovada em 2013, a proposta do Executivo Municipal apontava para a intensificação do uso do solo, especialmente das parcelas ainda vazias entre o Caminho Niemeyer e a parte consolidada do Centro histórico, prevendo prédios com até 40 pavimentos, concentrando a aplicação dos recursos arrecadados na operação na área já urbanizada, nada sendo proposto para melhorar as condições das parcelas mais precarizadas, como o maior complexo de favelas de Niterói que existe dentro dos limites da OUC.

Figura 3 - Mapa síntese das Propostas.

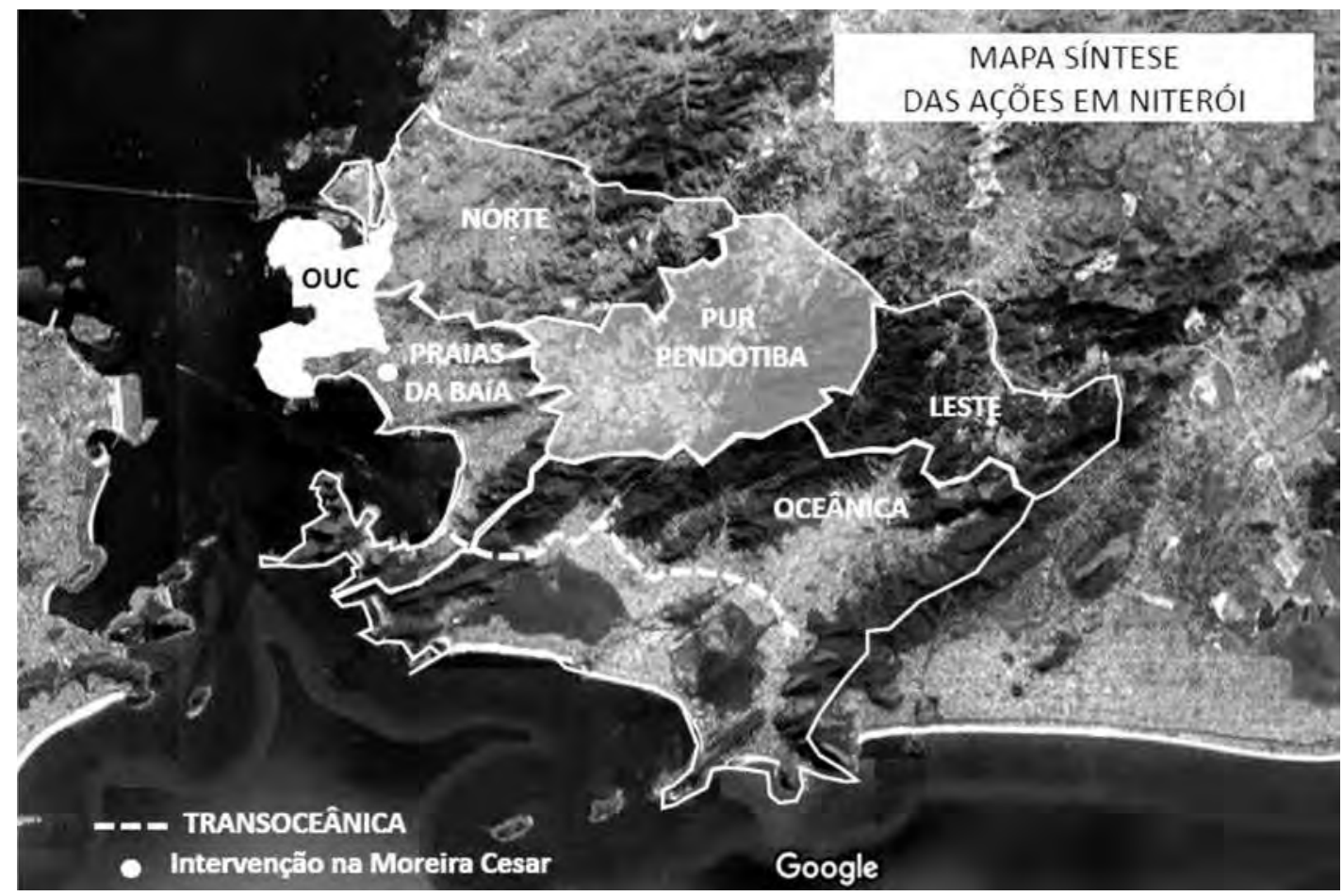

Fonte: Autor, sobre base do Google Maps, 2018. Disponivel em: 〈https://www.google.com.br/maps/@-22.9020619,-43.0891497,23386m/data=!3m1!1e3〉. Acesso em: 22.02.2018.

22 Lei $\mathrm{n}^{\circ}$ 2.657/2009 alterou a redação do artigo 10 da Lei $\mathrm{n}^{\circ}$ 1.779/00, que instituiu o "Caminho Niemeyer” e estabeleceu as condições especiais para uso e ocupação do sol e seu perímetro.

23 O Conselho Municipal de Urbanismo e Meio Ambiente, previsto pelo art. 102 da Lei $\mathrm{n}^{\circ}$ 1.157, de 29 de dezembro de 1992, foi alterado pela Lei Municipal $n^{\circ} .2 .123 / 2004$ que adequou o Plano Diretor ao Estatuto da Cidade e passou a denominar-se Conselho de Política Urbana de Niterói (Compur).

24 O Plano Municipal de Redução de Risco, coordenado pelo professor Elson Nascimento da Escola de Engenharia da UFF, foi elaborado durante a gestão de Godofredo Pinto (2007). 
Vale destacar que a literatura recente ressalta que as OUC's têm sido apresentadas como:

\begin{abstract}
um instrumento avançado para (a) viabilizar grandes obras, apesar das restrições orçamentárias, compatibilizando adensamento e capacidade da infraestrutura em determinado perímetro, (b) permitir que os beneficiários de uma obra paguem seus custos, liberando os recursos públicos para aplicação em investimentos prioritários; (c) possibilitar a recuperação da chamada "maisvalia urbana", capturando parte da valorização decorrente de um investimento público para que esta não seja apropriada unicamente pelos proprietários e promotores imobiliários (FIX, 2004, p.2).
\end{abstract}

Entretanto, diversos estudos, como - também - de Fix (2001, 2003, 2007), Ferreira e Maricato (2002), Vilarino (2006), Cardoso (2013), Santoro (2015), Diniz (2014), Autor et. al. (2015) e Autor (2016), apontam que esse instrumento não tem servido como forma de melhoria urbana para a população residente na região, mas sim, para viabilizar uma renovação urbana que geralmente se traduz em limpeza urbana ou mesmo na expulsão da população de baixa renda das áreas de maior centralidade da cidade.

Também em 2013, foi lançado o Plano Estratégico 2013-2033 “Niterói Que Queremos”, descrito como um novo modelo de governança pública apoiado na participação plena da sociedade que “(...) ocorreu em duas vertentes: a primeira na viabilização financeira para o processo de construção do Plano e a outra, por meio de sugestões, opiniões e análises acerca da cidade" (GOMES; REYS, 2015), demonstrando o estreito diálogo, parceria e afinidade com a iniciativa privada $^{25}$. Aqui também a parceria público-privada é justificada pelo cenário de precariedade e escassez de recursos financeiros, sendo alardeado que a única saída se daria pela aliança com a iniciativa privada que colocaria seu saber em termos de gestão, supostamente a serviço do desenvolvimento da municipalidade. O Plano indicava ações para o governo, na perspectiva macro de uso e ocupação do território, dentre outras propostas, apontando para a necessidade de uma nova ligação viária entre a Região das Praias da Baía e a Região Oceânica, o que logo foi eleita como a próxima prioridade no planejamento da cidade.

Buscando neutralizar as acirradas críticas realizadas por diversos setores técnicos e acadêmicos, a prefeitura acabou se comprometendo com a revisão do Plano Diretor. Contudo, quando parecia ter finalmente chegado a hora e a vez da revisão do Plano Diretor, este foi novamente postergado pela emergência em torno da realização do PUR-Pendotiba. Apresentado pelo Executivo municipal como resposta à demanda de seus moradores ${ }^{26}$, suas propostas foram calcadas no discurso da "cidade compacta", verticalizada e densificada, vislumbrando

25 Em 2013, a prefeitura estabelece parceria com o Movimento Brasil Competitivo - MBC, visando garantir a participação dos empresários da cidade, representados principalmente pela Associação Conselho Empresarial e Cidadania - ACEC, uma organização não governamental, fundada em 2005 que congrega empresas e entidades de classe que, juntas, representariam mais de $90 \%$ do PIB do município. A ACEC tinha como missão articular projetos e programas de forma a propor soluções para os problemas e contribuir para o desenvolvimento de Niterói (GOMES; REYS, 2015).

26 Os moradores demandavam a interrupção do processo de verticalização, iniciado com a aplicação da legislação em vigor na Região voltada para atender as classes populares (Plano de Arrendamento Residencial - PAR e PAR', respectivamente leis $n^{\circ} 1.763 / 99$, substituída pela lei $n^{\circ}$ $2.511 / 2007)$. 
alterações definitivas das características do local e da qualidade de vida da população ali residente. Embora estudiosos apontem para a economia gerada com a concentração de infraestrutura de saneamento e transportes através do aumento de densidade e promoção de eficiência energética em prédios, a cidade compacta é contestada por Acselrad (2009) quando este afirma que não há consenso sobre sua eficiência energética e nem de qualidade de vida e que também são atributos do espezinhado espraiamento, a descentralização e a baixa densidade, por recorrerem a fontes de energia e produção de alimentos em solos locais (ROBERTSON apud ACSELRAD, 2009, p.61). Assim, o PUR-Pendotiba acabou por contrariar a vontade de seus moradores por melhorias para o bairro, principalmente voltadas para mobilidade e para a regularização fundiária. Apesar de Pendotiba apresentar características remanescentes de área rural, com uma ocupação dividida entre condomínios horizontais das classes média e alta, que fugiram do adensamento e verticalização das Regiões mais centrais da cidade a partir dos anos 70, assim como por uma expressiva ocupação informal de famílias de baixa renda, pouca atenção e propostas contemplavam o tratamento dessas áreas (AUTOR, 2018).

Em resumo, se a Operação Urbana do Centro da cidade tinha o intuito de atender os interesses das grandes empresas da construção civil de porte nacional, o PUR-Pendotiba, ao que parece, surgiu como uma mediação do Executivo com as empreiteiras locais, ampliando a frente de expansão do mercado imobiliário na Região. Finalmente, agora era chegada a hora de dar continuidade à iniciada revisão do Plano Diretor, o que trataremos na parte a seguir.

\section{Apontamentos sobre a revisão do Plano Diretor}

\subsection{Conteúdo e discussão}

O processo de revisão do Plano Diretor de Niterói se deu a partir da contratação da Fundação Getúlio Vargas (FGV) em 2015²7, sendo dividido em três etapas: a primeira etapa é constituída pela Leitura da Cidade, quando seriam identificados quantos e quem são os seus habitantes, como vivem, como se deslocam, quais são suas atividades econômicas, sociais, culturais, como se organiza o novo quadro político-institucional, bem como Niterói se posiciona com relação a outras cidades, gerando o Diagnóstico Técnico que, a partir de sua discussão em Audiências Públicas, permitiria avançar para a segunda etapa, isto é, a construção de dois cenários: o inercial e o desejável e a terceira etapa seria a definição de diretrizes e instrumentos do novo Plano Diretor Participativo, concebidas a partir da definição na segunda etapa, do Cenário Desejável para Niterói ${ }^{28}$. Estas etapas, de acordo com o discurso oficial, corresponderiam às etapas participativas, quando ocorreria a contribuição da população. O Executivo não colocou o projeto de lei para discussão popular, antes de ser encaminhado à Câmara para ser votado, e assim, a população não chegou a tomar conhecimento das propostas efetivas.

\footnotetext{
27 "Para colaborar com o estudo, a instituição foi contratada por $R$ \$ 1,9 milhão com dispensa de licitação. Na época da contratação, o município justificou que a escolha da fundação sem concorrência pública se deu por "notoriedade e experiência" em projetos de porte semelhante, conforme prevê a Lei de Licitações. ” (Disponível em: <https://oglobo.globo.com/rio/bairros/prefeitura-de-niteroiconclui-diagnostico-do-novo-plano-diretor-1-17269319>, acesso em 18.02.2018).
}

28 Disponível em: http://urbanismo.niteroi.rj.gov.br/wp-content/uploads/2015/09/SMU_ ANUNCIO\%20REVISAO\%20PLANO\%20DIRETOR_01.pdf 
Gráfico 01: Progressão do crescimento populacional, cenários.

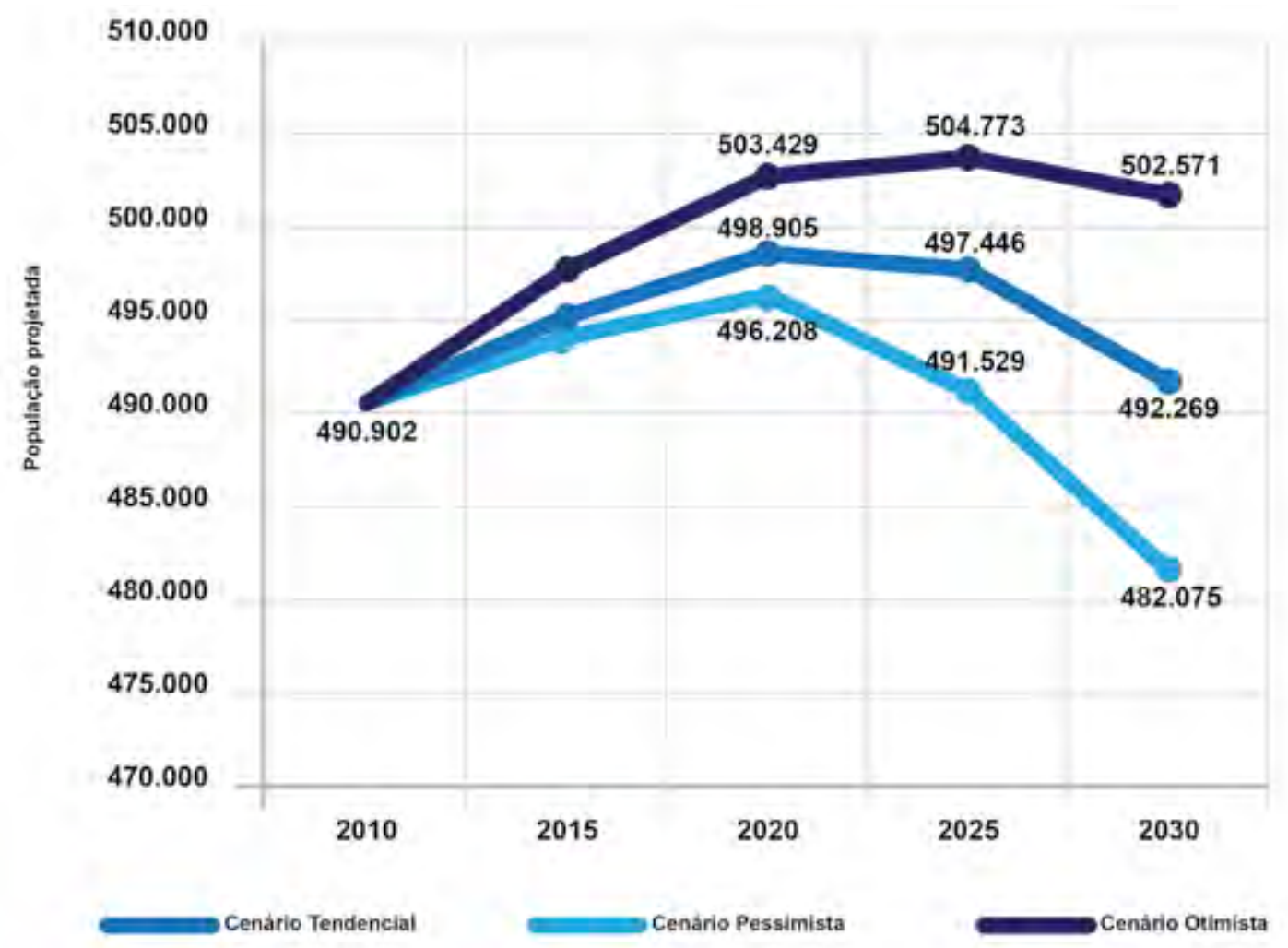

Fonte: Apresentação Audiências Públicas etapa Cenários ${ }^{29}$, PMN/FGV, set. 2015. p.51

O diagnóstico ressalta as qualidades do município em termos de paisagens e cenários que se deseja construir. A cidade é descrita com potencialidades não aproveitadas, especialmente as ambientais, pouco se detendo nas desigualdades nela presentes. Entre os principais problemas destacados está o que é descrito como um crescimento espraiado da malha urbana, geralmente unifamiliar, que acarretaria um uso inadequado dos investimentos na infraestrutura da cidade, justificado por exigir um custo mais elevado para sustentar a infraestrutura para uma baixa densidade. Ou seja, aponta ser necessário corrigir essa distorção por meio da permissão e incentivo ao adensamento. Porém, os próprios estudos da FGV indicavam um crescimento populacional negativo para os próximos anos (Gráfico 01).

A partir desta leitura do município, foram definidos 196 diretrizes, 517 objetivos e 51 ações. A divisão administrativa em cinco Regiões, vigente no plano atual foi ignorada, sendo adotada uma nova organização, nomenclatura e conceitos. O Plano propõe a divisão do território municipal em três Macrozonas: 1- Marinha (Macrozona de Estruturação e Qualificação do Ambiente Urbano); 2- Ambiental (Macrozona de Proteção e Recuperação do Ambiente Natural), e; 3- Urbana (Macrozona do Ambiente Costeiro e Marinho), que se sendo subdividem em Macroáreas (Figura 4). <http://urbanismo.niteroi.rj.gov.br/wp-content/uploads/2015/09/PDDU_CENARIOS_ APRESENTACAO-AUDIENCIAS-PUBLICAS.pdf $>$. 
Figura 4: Macrozonas e Macroáreas.

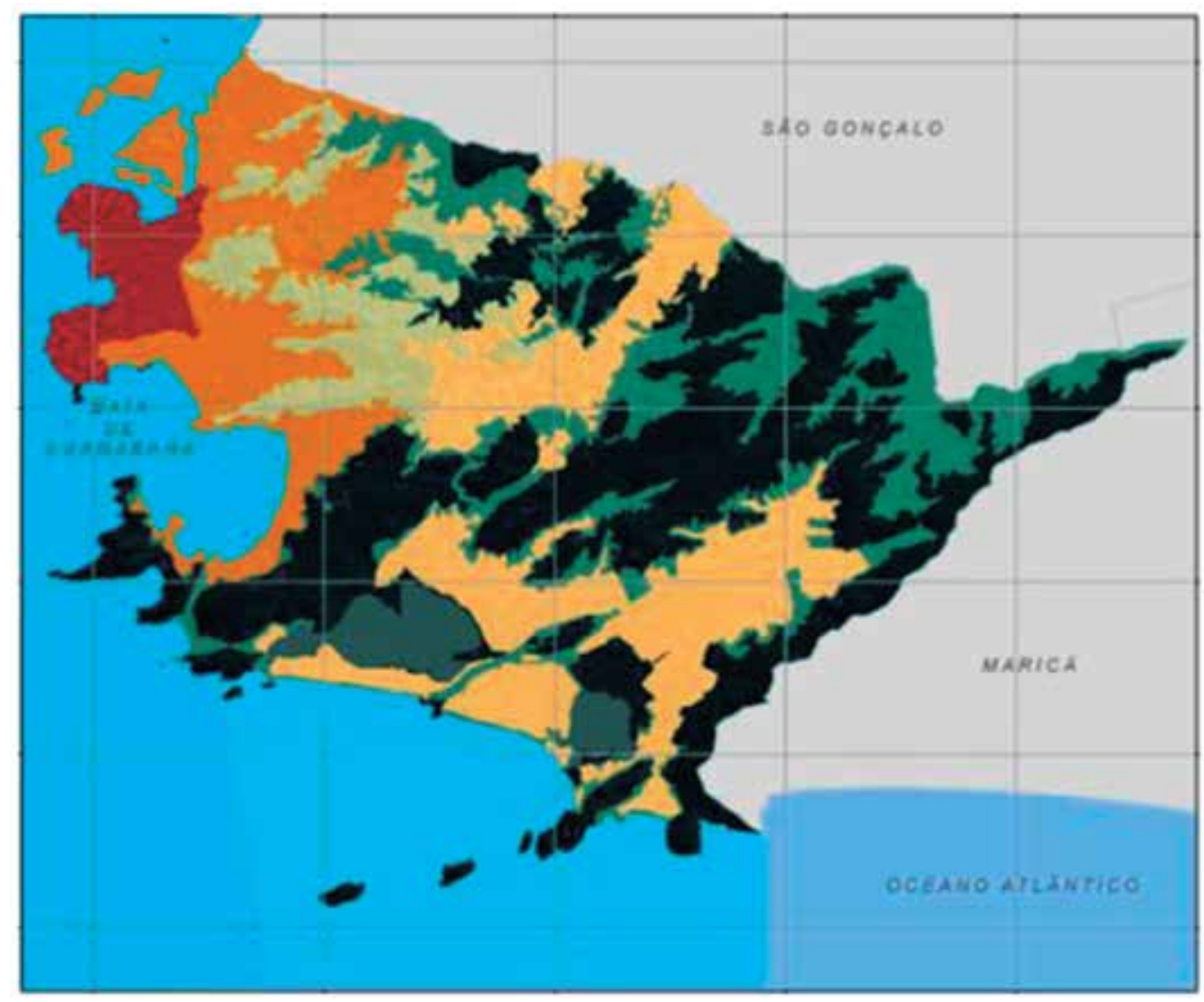

Fonte: Mapa 3. Projeto de Lei nć 008/2017

A área urbana está dividida em quatro Macroáreas, seguindo do Centro em direção à periferia: 1- Integração Metropolitana (em vermelho), compreendida por quase a totalidade da área da OUC-Centro, sendo previsto seu crescimento acelerado; 2- Urbanização Consolidada (laranja), descrita como apresentando saturação viária, construtiva e habitacional, além da coexistência de bairros nobres e favelas, estando indicado seu adensamento de acordo com a infraestrutura disponível; 3- Promoção da Equidade e Recuperação Ambiental, (cinza), tendo como principal característica a vulnerabilidade social, as diretrizes sendo prevenir surgimento de favelas e construir habitação popular e 4- Qualificação Urbana (bege), considerada a principal área de expansão urbana, sendo proposto o adensamento intermediário e a melhoria das condições urbanísticas. As duas áreas em verde são representativas das áreas ambientais, ou Macrozona Proteção e Recuperação do Ambiente Natural, sendo a mais escura de maior restrição e, em dois tons de azul, a Macrozona do Ambiente Costeiro e Marinho, dividida entre a costa da Baía e a costa oceânica.

No texto do projeto de lei, é clara a ênfase na questão ambiental, o que, aliás, corresponde à leitura constante do diagnóstico que ressalta o potencial e a necessidade de proteger e integrar fragmentos florestais, de preservar e reflorestar topos de morros, desocupar faixas de proteção de rios e lagoas, o que frequentemente poderia corresponder à remoção de assentamentos populares aí existentes.

As propostas são, em geral, genéricas, prevendo-se o desenvolvimento de planos temáticos específicos a serem aprovados posteriormente, sem que 
sejam estabelecidos prazos. A nova divisão do território em Macrozonas e Macroáreas, retirando a base territorial anterior dos Planos Urbanísticos, passa a exigir uma nova base legal para a definição das normas do uso e ocupação do solo, o Plano de Uso e Ocupação do Solo, incluindo parâmetros de parcelamento do solo, que irá substituir os PUR's, inclusive o da Região de Pendotiba, recém-aprovado. Nesta linha de ação, estão também previstos os Planos de Regularização Fundiária, Mobilidade, Saneamento Ambiental, devendo chegar a um Plano de Arborização e à revisão do Plano Municipal de Redução de Risco, elaborado em 2007 e do Plano de Habitação de Interesse Social, elaborado em 2012, ambos não transformados em lei.

O conteúdo hermético, por vezes dúbio, dificulta a correta compreensão do texto, até por parte dos técnicos e ativistas envolvidos na leitura e avaliação do Projeto de Lei. Além disso, expressões relativas, por exemplo, à indicação de participação social, precedidas de "sempre que possível”, imprime um caráter discricionário a algumas decisões.

As diretrizes apontam para a necessidade de conter o crescimento dos assentamentos populares precários e, conforme já apontado, desocupar topos de morros e áreas de proteção ambiental, muitos desses locais ocupados há várias décadas, sem, no entanto, definir ações específicas ou reservar áreas vazias para a produção de novas moradias. Na verdade, frente a essas diretrizes, chama a atenção a não demarcação de vazios urbanos e imóveis subutilizados que poderiam contribuir para a formação de um estoque de terras a ser utilizado para habitação de interesse social. Claro está que, tal fato irá dificultar, senão inviabilizar, a implementação futura de instrumentos do Estatuto da Cidade que poderiam permitir a correção, ainda que em pequenas proporções, da desigualdade e da injustiça social presentes na cidade. Neste mesmo sentido, apesar do número de moradias em assentamentos ter aumentado, a demarcação de Áreas Especiais de Interesse Social, voltadas para a proteção dos espaços populares precários existentes, não correspondeu a esse crescimento, mas ao contrário, foi reduzido em número e área, comparativamente ao Plano Diretor de 1992.

Por outro lado, apesar de não conter propostas explícitas de remoção, a indicação de "desocupação de áreas de risco de deslizamento ou situadas no interior de áreas verdes legalmente protegidas contemplando, sempre que possível, a participação da população local nas decisões" (Inciso V do artigo 18) (grifo nosso) e a promoção da urbanização e regularização fundiária de assentamentos “(...) exceto nas áreas de risco e de preservação ambiental” (Inciso VI do artigo 18) (grifo nosso) sugerem que a alternativa poderá ser utilizada em nome da preservação ambiental. Isto expressa o que alguns autores têm descrito como uma suposta contradição entre o direito à moradia e a preservação ambiental (REFINETTI, 2006). Essa diretriz é reforçada no Artigo 21, o inciso VIII, quando aponta que deverá ser evitada “(...) ocupação irregular em áreas de preservação e áreas de risco por meio de contínuo monitoramento do poder público e da intensificação das ações de produção habitacional de interesse social e de educação ambiental", sem, contudo, a previsão de ações efetivas que ofereçam alternativas de moradia às classes populares na cidade. Vale ressaltar que nos três incisos supracitados, a palavra "remoção" parece ter sido substituída por "desocupação". Além disso, a solução para as situações de risco existentes não parece considerar medidas corretivas de drenagem e contenção, hoje disponíveis, e que possibilitariam a permanência das moradias em tal situação. 
A busca por uma cidade compacta justifica a proposta de adensamento e verticalização de novas áreas, ainda desocupadas ou com ocupação espraiada e unifamiliar, modificando as características da ocupação existente e tendendo a uniformizar a ocupação em todo o território municipal. São claramente abertas novas fronteiras para exploração pelo capital imobiliário, em geral associadas com projetos prévios já mencionados neste artigo, como o Corredor Transoceânico, onde as Macrozonas de Ocupação Consolidada e Qualificação Urbana se aproximam a partir da construção do túnel CharitasCafubá, inaugurado em 2017. Os elevados investimentos realizados, por exemplo, com este Corredor passam a exigir a perspectiva de ocupação do território com novos contribuintes que possam vir a atender o pagamento desta dívida. Esta também parece ser a alternativa adotada para a Região de Pendotiba, apesar das projeções demográficas indicarem o contrário.

Em termos da gestão democrática, o Plano propõe um sistema municipal de planejamento urbano e gestão democrática, composto por um Comitê Gestor, Núcleo de Informações estratégicas, Compur, Conselho Gestor do Fundo de Desenvolvimento Urbano, além dos instrumentos listados no Estatuto da Cidade, sem especificar a composição dos Conselhos, exceto o Compur, já existente, ficando a decisão nas mãos do Executivo municipal.

\subsection{Processo de participação desenvolvido: limites e oportunidades}

O processo de revisão do Plano Diretor não foi marcado por uma participação social intensa; muito pelo contrário! O que se observa é um processo de esvaziamento participativo motivado principalmente pelas atitudes do Executivo. Avalia-se (e identifica-se) que tal esvaziamento decorre seja da falta de divulgação ou de divulgação não apropriada, seja por conta da forma pela qual o processo de discussão ou pela não aceitação das demandas da população. Ele se expressa, notadamente, por intermédio da desistência da população em se envolver nos processos conclamados pela prefeitura. Nos três processos discutidos na segunda parte deste artigo ficou claro o que seria entendido pelo Executivo municipal como sendo o quesito participação.

Pelo que se pôde perceber até o momento da redação deste artigo, a mecânica utilizada pelo Executivo foi a de divulgar, de forma restrita, embora respeitando às exigências legais, as convocações para as audiências públicas, sem ampla informação por todo território da cidade. Estas por sua vez, foram apresentadas em um formato de longas e repetidas explicações sobre o Plano, em linguagem técnica, sem avançar e destrinchar os detalhes, à medida que se tornavam complexas. De maneira semelhante, a distribuição do tempo de participação, nunca voltado para realização de debates com a plateia, sempre priorizou o tempo de explanação do Executivo, restando à população apenas três minutos de intervenção sem direito à tréplica, tornando com isto, o diálogo limitado e por vezes incoerente.

Após algumas audiências públicas de apresentação de cenários, ocorridas no segundo semestre de 2015, em fevereiro de 2017, o Projeto de Lei ${ }^{\circ}$ 008/2017, referente ao Plano Diretor, foi encaminhado à Câmara para sua apreciação. Já na fase de discussão e aprovação do projeto de lei na Câmara Municipal, foi necessário mobilização popular ${ }^{30}$ para aumentar o número de audiências 
públicas para 12, no lugar das quatro inicialmente previstas, o que poderia ser considerado uma vitória do movimento ${ }^{31}$.

Noentanto,aparticipaçãodos vereadoresnasaudiências públicas foiextremamente reduzida, o que, além de apontar para o possível descaso com as demandas da população, que posteriormente serão votadas, pode também ser indicativa do forte vínculo e mesmo do apoio irrestrito da grande maioria dos vereadores às propostas colocadas pelo Executivo, o que retiraria a necessidade de auscultar a população. Assim, apesar de aceita a proposta encaminhada pelos moradores para aumentar o número de audiências públicas, as demandas da população tiveram um efeito restrito, já que as votações posteriores na Câmara Municipal ocorrerão $^{32}$, independentemente das expressões e propostas apresentadas pela população ao longo das audiências conquistadas.

Vale ressaltar que, no decorrer da tramitação do processo de aprovação do projeto de lei, houve a oportunidade de abrir o diálogo entre as comissões permanentes de Urbanismo e de Meio Ambiente da Câmara, os mandatos de alguns vereadores e o Executivo. Com isso, ampliou-se a possibilidade de parte das demandas populares ser aprovada. Entre as reivindicações reforçadas estavam o aumento do número de ZEIS e a proteção de áreas residenciais de modo a impedir o adensamento e a verticalização.

No entanto, o fato do Executivo alterar seu próprio projeto, por meio do encaminhamento de emendas às referidas comissões, tem dificultado o devido controle social por parte da população já que tais alterações apenas serão apresentadas no dia da votação ou, no máximo, em dias muito próximos a elas, sem que haja tempo necessário para o estudo e avaliação das alterações do Executivo e se, efetivamente, elas são concernentes ao desejo expresso pela população. Por outro lado, o trâmite adotado no momento da votação também dificulta o acompanhamento e um controle social mais apurado, já que as emendas geralmente não são lidas, apenas sendo citado seu número. Com o objetivo de ter maior transparência no processo de votação, o Fórum de Política Urbana de Niterói (Fopur) ${ }^{33}$ encaminhou ao presidente da Câmara e aos 21 parlamentares, carta subscrita por 27 entidades de Niterói, com solicitação da apresentação individual de cada emenda, antes da sua votação, de modo que a assistência, a partir das galerias do plenário, possa acompanhar uma a uma as suas demandas.

\section{Considerações (nem tanto) finais}

A reflexão, ainda que preliminar, sobre o processo de revisão do Plano Diretor de Niterói, realizado por meio de um esforço coletivo levado pelo Núcleo de Estudos e Pesquisa Habitacionais e Urbanas (NEPHU) da Universidade Federal Fluminense (UFF), através de seu programa de extensão "A Universidade pública e o direito à cidade: assessoria a movimentos sociais do Estado do Rio de Janeiro”, com o objetivo acompanhar os processos conflituosos em relação ao direito à moradia e à cidade na cidade objeto deste artigo, apontou um conjunto de inferências que são a seguir brevemente indicadas.

31 Gravações do PD. Disponíveis em: <https://wp.me/p2HQHE-a9>. Acesso em: 19, 20 e 21/02/2018.

32 Até o momento, o Plano Diretor foi votado em primeira instância, estando prevista a segunda votação para o mês de março de 2018.

33 O Fopur foi criado em 2012, por associação informal de ativistas mobilizados em torno das discussões sobre questões urbanas e políticas públicas em Niterói. 
Não seria exagero afirmar que ao longo da história político-administrativa recente da cidade, as sucessivas administrações municipais, de forma consciente ou inconsciente articulada ou não, consolidaram duas narrativas que, no caso brasileiro, se combinaram: uma identificada com a necessidade de enfrentar o quadro de crise (fiscal e, consequentemente, de financiamento) que o país vivenciou na década de 1980, no contexto do processo de redemocratização brasileiro que, por sua vez, possibilitou a emergência de um conjunto de demandas sociais e políticas até então reprimidas. A outra, resultante das novas orientações e/ou modelos oriundos do Norte global desenvolvido, com vistas ao enfrentamento do quadro de crise instaurado pelos então recentes avanços da microeletrônica e da automação, os quais, associados a uma nova configuração da relação entre capital e trabalho, a partir da exportação de unidades produtivas para outras regiões do globo, tendo a China como exemplo emblemático, colapsou a velha estrutura produtivo-industrial existente, requerendo novos modos de gestão e planejamento da economia e, consequentemente, das cidades.

Neste contexto, a ideia de um instrumento de considerável e importante abrangência como é o Plano Diretor foi, de certa maneira, secundarizado, uma vez que, após sucessivos adiamentos, vem sendo consolidada através de um híbrido que mescla o nome "Plano Diretor" com o ideário e as diretrizes do que tem sido nomeado de planejamento estratégico, com seus cenários (possíveis) e a quase total desconsideração da cidade real que desafia intensa e cotidianamente as propostas imaginadas pelos setores hegemônicos, através de um corpo técnico a eles aliados. Assim sendo, o caráter engessador, não condizente com os novos imperativos da reestruturação econômica capitalista mundial, reconhecido e sobejamente criticado dos antigos planos diretores, se transmuta e se traveste, no seu conteúdo, de um "novo" formato de planejamento, o qual é guiado pelos ditames do mercado e está voltado para atrair novos investimentos. Surge e se afirma nas cidades a partir do mercado, principalmente o imobiliário, e da relação patrimonialista ainda bastante presente (MARICATO, 2000). Este processo reafirma um desenvolvimento caracterizado por ser seletivo, isto é, alcança apenas alguns setores da economia e também por ser excludente no que se refere à dimensão social (somente certas classes sociais se aproveitam dessa situação). Essa nova agenda se expressa e se desdobra na crescente privatização da vida cotidiana, ou seja, na "venda" de parcelas da cidade, na construção de grandes objetos arquitetônicos, por vezes icônicos, que se viabiliza, muitas vezes pela adoção, cada vez mais frequente, de parcerias público-privadas e do planejamento estratégico e pontual, sempre buscando a possibilidade de ampliar seus negócios sobre parcelas da cidade. Em paralelo a esse cenário, o aumento da pobreza e da violência urbana e seu rebatimento no espaço construído, com a informalidade e a precariedade crescente, expressam o outro lado da sociedade e da vida urbana.

No caso da cidade de Niterói, avalia-se que isto não significou uma adesão total e mecânica aos mesmos, especialmente por conta das peculiaridades sociais, políticas e econômicas do município. Ou seja, a coalisão de forças que sustentou os projetos de governo que foram levados a cabo pelas supracitadas administrações desde o fim do período militar, ou seja, desde o final da década de 1980, tiveram, não sem alguns constrangimentos, uma certa continuidade que se refletiu na crescente prioridade dos projetos ditos estratégicos e/ou pontuais como forma principal de gestão e planejamento. Isto se deu, por exemplo, na ideia do resgate do orgulho e da sensação de identidade e pertencimento inauguradas por Jorge Roberto Silveira; na busca de visibilidade da cidade no "mapa do mundo", por assim dizer, especialmente a partir da construção do Museu de Arte Contemporânea, 
MAC, e que deu origem ao "Caminho Niemeyer", durante a gestão de João Sampaio; nas tentativas de "renovar" a área central da cidade, por intermédio, por exemplo, da proposta “Niterói Centro Master Plan 2026”, durante o governo Godofredo Pinto e, finalmente, na proposta da Operação Urbana Consorciada do Centro, OUC-Niterói, na construção do túnel Charitas-Cafubá, na implementação da Transoceânica, na realização do Plano Urbanístico Regional de Pendotiba, PUR-Pendotiba, nos dois sucessivos mandatos de Rodrigo Neves.

Desse modo, instaura-se no município de Niterói uma disputa (desigual, para dizer o mínimo) entre dois projetos de cidade, a saber: um que defende a garantia da função social da propriedade e da cidade, viabilizada pela Constituição de 1988 e reafirmada no Estatuto da Cidade, a partir de 2001, onde o Plano Diretor é entendido enquanto principal instrumento de planejamento urbano, devendo compreender o desenvolvimento do município, e outra que, conforme indicação anterior, se restringir apenas a um conjunto de propostas físico-espaciais voltadas para a espetacularização da parcela da cidade "formal", solvável e predominantemente branca.

Para tanto, em consonância, supostamente, com as demandas requeridas pela ordem democrática ainda vigente no país, as sucessivas administrações buscaram, de diferentes modos, legitimar suas respectivas propostas e ações utilizandose, principalmente, da cooptação de lideranças comunitárias, assim como de procedimentos que, pelo menos na aparência, têm garantido a aprovação das mencionadas propostas, através de audiências públicas cuidadosamente pensadas e presididas de forma a transformá-las numa arena controlada de discussão. A articulação, muitas vezes perversa de tais estratégias, acabou resultando naquilo que poderíamos nomear de "democracia na medida dos interesses daqueles que detêm o poder", de um lado, e da tendência ao esvaziamento dos processos decisórios, de outro. Mesmo assim, foi possível observar o surgimento de grupos sociais que, conseguindo permanecer fora dos esquemas de cooptação, se organizaram, construindo um novo movimento em defesa da função social da cidade. Assim, o processo vivido na revisão do Plano Diretor teve resultados positivos, pois contribuiu com a reaproximação de diversas comunidades, movimentos sociais e da universidade pública, que juntos e, como um desdobramento, criaram o Fórum de Luta pela Moradia, que pretende ser um espaço constante de debates e articulações na defesa dos territórios populares e na luta por direitos, para além das discussões institucionais, como a revisão do Plano Diretor. Hoje ele conta com a presença das seguintes comunidades, como Morros da Chácara, Arroz e Estado (Centro), Castro Alves (Fonseca) Lazareto, Peixe Galo e Salinas (Jurujuba), Ocupação Mama África (São Domingos), Fazendinha (Sapê), Cantagalo (Pendotiba), Colônia de Pescadores da Ponta da Areia (Ponta da Areia), Beira da Lagoa de Piratininga (Piratininga), Colônia de Pescadores de Itaipu (Itaipu).

É neste contexto, que se colocam os desafios e enfrentamentos para os segmentos e coletivos sociais e políticos organizados efetivamente comprometidos com as lutas por uma cidade mais justa e equânime. 


\section{Referências bibliográficas.}

ACSELRAD, Henri. Sentidos da sustentabilidade urbana. In: A duração das cidades. Sustentabilidade e risco nas políticas urbanas. $2^{\mathrm{a}}$ ed. Rio de Janeiro: Lamparina, 2009. p. 43- 70.

AUTOR, et. al., 2012.

AUTOR, et. al., 2015.

AUTOR, 2016.

AUTOR, 2018.

BORJA, Jordi (ed.). Barcelona: un modelo de transformación urbana. Quito: Programa de Gestión Urbana - Oficina Regional para América Latina y Caribe, 1995.

BRASIL. Estatuto da Cidade: Lei $\mathrm{n}^{0}$ 10.257/2001 que estabelece diretrizes gerais da política urbana. Brasília, Câmara dos Deputados, 2001, 1ª Ed.

CARDOSO, Isabel Cristina da Costa. O papel da Operação Urbana Consorciada do Porto do Rio de Janeiro na estruturação do espaço urbano: uma "máquina de crescimento urbano"? Rio de Janeiro: O social em questão, ano XVI, n. 29, p. 69-100, jan. 2013.

DINIZ, Nelson. Da emergência do imaginário da revitalização ao Porto Maravilha. Letra Capital. 2014.

FERREIRA, João Sette Whitaker.; MARICATO, Ermínia. Operação Urbana Consorciada: diversificação urbanística participativa ou aprofundamento da desigualdade? In: OSÓRIO, L. M. (Org.). Estatuto da Cidade e Reforma Urbana: novas perspectivas para as cidades brasileiras. Porto Alegre: Sergio Antonio Fabris Editor. 2002. p. 215-25.

FIX, Mariana. Parceiros da exclusão. Duas histórias da construção de uma “nova cidade” em São Paulo: Faria Lima e Água Espraiada. São Paulo: Ed. Boitempo. 2001.

A "fórmula mágica" da parceria público-privada: Operações Urbanas em São Paulo. In: SCHICCHI, M. C; BENFATTI, D. (Orgs.). Urbanismo: Dossiê São Paulo - Rio de Janeiro. 1ed.Campinas: PUCCAMP/PROURB, p. 185-198, 2004.

. São Paulo, cidade global: fundamentos financeiros de uma miragem. São Paulo: Boitempo. 2007.

G1 RIO. Rodrigo Neves é eleito prefeito de Niterói, no RJ. Rio de Janeiro: O Globo, 20 out. 2012. Disponível em: <http://g1.globo.com/rio-de-janeiro/ eleicoes/2012/noticia/2012/10/rodrigo-neves-e-eleito-prefeito-de-niteroi-norj.html>. Acesso em: 12 nov. 2016.

GOMES, Andréa Mayer; REYS, Pedro da Silva. Niterói Que Queremos: uma estratégia inovadora de planejamento. Brasília: VIII Congresso CONSAD de Gestão Pública, Painel 34/104, Práticas Participativas em Governos Municipais, 2015.

HARVEY, David. Do gerenciamento ao empresariamento: a transformação da administração urbana no capitalismo tardio. São Paulo. Espaço e Debates, ano XVI, n ${ }^{\circ} 39,1996$, p.48- 64.

MARICATO, Ermínia. As ideias fora de lugar e o lugar fora das ideias: 
Planejamento urbano no Brasil. In: ARANTES, O.; VAINER, C.; MARICATO, E. 2000. A cidade do pensamento único: desmanchando consensos. Petrópolis: Editora Vozes, 2000.

OMENA, Erike, A copa das manifestações e os processos de governança urbana no Brasil. In: Brasil o impacto da copa do Mundo 2014 e das Olímpiadas 2016. SANTOS JÚNIOR, Orlando Alves dos et al. (Orgs.). Rio de Janeiro, E-papers, 2015.

PMN/FGV. Apresentação Audiências Públicas etapa Cenários, set. 2015. Disponível em: <http://urbanismo.niteroi.rj.gov.br/wp-content/ uploads/2015/09/PDDU_CENARIOS_APRESENTACAO-AUDIENCIASPUBLICAS.pdf $>$.

REFINETTI, Maria Lucia. Moradia e Mananciais: Tensão e dialogo na metrópole. São Paulo, FAUUSP / FAPESP, 2006.

RIBEIRO, Luiz Cesar de Queiroz; SANTOS JÚNIOR, Orlando Alves, GAFFNEY, Christopher (Orgs.). Brasil: os impactos da Copa do Mundo 2014 e das Olimpíadas 2016. Rio de Janeiro. 2015. $1^{\text {a }}$. ed Recurso eletrônico. Disponível em: <http://www.observatoriodasmetropoles.net/images/abook_ file/livro_megaeventos_2015.pdf>.

SANTORO, Paula Freire; LIMA, Pedro; MENDONÇA, Pedro. Formas de garantia do direito à moradia em um contexto de produção da habitação pelo mercado através de instrumentos de transformação urbana - os casos da OUC Água Branca e da PPP Habitacional em São Paulo. Seminário Internacional Public-Private Partnerships and The Real Estate/Financial Complex. São Paulo: FAUUSP, 2015.

VAINER, Carlos B. Pátria, empresa e mercadoria. In: ARANTES, Otília; VAINER, Carlos; MARICATO, Ermínia. (Orgs.). A cidade do pensamento único: desmanchando consensos. Petrópolis: Vozes, 2000, p. 75-104. $1^{\mathrm{a}}$ ed.

VILARINO, Maria do Carmo. Operação Urbana: A inadequação do instrumento para a promoção de áreas em declínio. (Tese de doutorado). São Paulo. 2006.

VILLAÇA, Flávio. Uma contribuição para a história do planejamento urbano no Brasil. In: DEÁK, Csaba; SCHIFFER, Sueli Ramos (Orgs.). O processo de urbanização no Brasil. $2^{a}$ ed. São Paulo: FUPAM/EDUSP, 2010. p.170-243.

\section{OUTRAS REFERÊNCIAS}

$<$ https://leismunicipais.com.br/plano-de-zoneamento-uso-e-ocupacao-dosolo-niteroi-rj>

<https://leismunicipais.com.br/a/rj/n/niteroi/lei-ordinaria/1999/173/1732/ lei-ordinaria-n-1732-1999-estabelece-normas-para-aplicacao-de-operacaointerligada>

<http://urbanismo.niteroi.rj.gov.br/wp-content/uploads/2015/09/SMU_ ANUNCIO\%20REVISAO\%20PLANO\%20DIRETOR_01.pdf>

$<$ https://wp.me/p2HQHE-a9>

$<$ http://urbanismo.niteroi.rj.gov.br/wp-content/uploads/2015/09/PDDU_ CENARIOS_APRESENTACAO-AUDIENCIAS-PUBLICAS.pdf>. 